International Journal of Engineering \& Technology, $7(2.29)(2018) 557-563$
International Journal of Engineering \& Technology
SPC
Website: $w$ ww.sciencepubco.com/index.php/IJET
Research paper

\title{
The Influence of Belief, Utility of Information, and Group Support on Selective Exposure to Pornography Among Teenagers in Jakarta, Indonesia
}

\author{
Inge Hutagalung \\ Universitas Mercu Buana, Indonesia \\ *Corresponding Author E-Mail: Inge_Hutagalung@Mercubuana.Ac.Id
}

\begin{abstract}
Festinger's (1) hypothesis cites belief as a variable that influences selective exposure. However, a review of other experts' research proves that selective exposure is not only affected by the psychological aspect but by the message and the social aspect as well. In contrast to previous scholars who focused only on one variable, the researcher examines belief, utility of information, and group support simultaneously and integrates them into a model. The research design is a case study involving the use of pornographic information. This study's subjects comprise 400 senior high school students in Jakarta, Indonesia. The relationships among the variables were tested by using structural equation modeling. The validity and reliability analyses utilized the LISREL 8.80 application. A questionnaire with a Likert-scale model was used as the data collection method. The structural test results show that the theoretical models for the three variables have a significant effect on selective exposure $(t$ value $\geq 1.96)$. On the other hand, the findings also prove that communication in the context of selective information on pornography is divided into three levels. First, at the intrapersonal level, the individual holds on to his or her belief in selecting the information. Second, at the interpersonal or group level, the individual adjusts his or her belief to the existing reality (environment or social group). Third, at the mass communication level, the individual selects the information according to its utility, that is, to fulfill the need for information.
\end{abstract}

Keywords: belief; utility of information; group support

\section{Introduction}

Pornography is one of the social problems in Indonesia that needs to be addressed with regard to the remarkable development of information and communication media technology. Based on Google Trends data in 2015, Indonesia ranked first in the world in terms of the number of entries of the keywords "sex" and "pornography" on Internet search engines. Jakarta was the fourth (after Delhi, Hanoi, and Mumbai) on the list of cities where the most number of people entered the keyword "sex." Disturbingly, an indepth examination revealed that teenagers comprised the largest group of users accessing pornographic materials (2).

The development of information and communication technology has also triggered changes in information consumption patterns from passively watching television (TV) or listening to the radio to actively seeking information by using search engines (e.g., Google or Yahoo) and search buttons (on the TV's remote control). Individuals have become actively engaged in their selective exposure to information in accordance with their interests and needs $(3,4)$.

The changes in information consumption patterns in the context of pornography give rise to the question: If people actively define and choose information, then what factors influence their selective exposure?

Festinger's (1) selective exposure hypothesis identifies an individual's psychological condition as the cause of one's choice or avoidance of information. This hypothesis views individuals as active information-processing entities who internally have the power and the ability of selective exposure to information in an effort to achieve cognitive harmony. This condition seems aligned with the position of the cognitive dissonance theory (as the source of the selective exposure concept), which is known as the theory of the individual, in which the emergence of dissonance and application is assumed to occur through the person's mental process (5) Festinger's (1) study focused more on the psychological aspect (belief). In contrast, subsequent studies conducted by other experts (6-10) have proven that the behavior involving selective exposure is not caused merely by the psychological aspect but also by the message and the social aspect (see Table 1).

Table 1: Study on Selective Exposure Aspects

\begin{tabular}{|c|c|}
\hline ASPECT & VARIABLE \\
\hline Psychology & $\begin{array}{l}\text { 1. Belief: Festinger, 1957; Ehrlich et.al., 1957; } \\
\text { Adams, 1961; Mills, 1965a; Rosen, 1961; } \\
\text { McFarland and Warren, 1992; Chafee et.al, } \\
\text { 2001; Redlawsk 2002; Taber and Lodge, 2006; } \\
\text { Bobkowski, 2007. } \\
\text { 2. Commitment: Brehm and Cohen, 1962; Mills } \\
\text { and Ross, 1964; Mills, 1965; Behling, 1971; } \\
\text { Lawson, 1969. } \\
\text { 3. Self-confidence: Festinger, 1964; Freedman, } \\
\text { 1965; Lowin, 1969 } \\
\text { 4. Mood: Zillman and Bryant, 1985; Davies, 2004. }\end{array}$ \\
\hline Message & $\begin{array}{l}\text { 1. Information Assurance Concept: Mills and } \\
\text { Ross, 1964. } \\
\text { 2. Information Relevance Concept: Mills and } \\
\text { Jellison, 1968. } \\
\text { 3. Utility of Information: Festinger, 1964; } \\
\text { Freedman and Sears, 1965; Freedman, 1965a; }\end{array}$ \\
\hline
\end{tabular}




\begin{tabular}{|c|l|}
\hline & $\begin{array}{l}\text { Cotton, 1985; Frey, 1986; Knobloch et.al, 2003, } \\
2005 .\end{array}$ \\
& 4. \\
& $\begin{array}{l}\text { Refutability: Lowin, 1967; Brock and Balloun, } \\
1967 .\end{array}$ \\
\hline Social & $\begin{array}{l}\text { 1. } \\
\text { 2. Group/Social Norms: David, 2005. } \\
\text { Group Support: Schulman, 1971; Dohyun, } \\
\text { 2010. }\end{array}$ \\
\hline Source: (11)
\end{tabular}

On the other hand, the explanation related to the selective exposure phenomenon over the last decade becomes less satisfactory when it is only explained by the effect of one variable since it has been proven that several variables from various aspects are involved.

Realizing that existing studies on the factors causing selective exposure have only focused on a certain variable and understanding that communication behavior involves many perspectives (12), this researcher tries to examine and integrate the effects of three aspects that have been widely studied regarding selective exposure, using a model emphasizing pornographic information. In contrast to earlier studies that only focused on a particular variable, this study simultaneously examines three variables using a single model. This integrated study is expected to explain comprehensively the variables that affect selective exposure by expanding on Festinger's (1) hypothesis.

\section{Literature Review}

\subsection{Selective exposure theory}

Selective exposure (from the perspective of the cognitive dissonance theory) was first introduced by Festinger (1). According to him, selective exposure is a person's attempt to reduce or eliminate cognitive dissonance. When an inconsistency or dissonance occurs, people look for information to reduce the inequality in attitudes and behaviors. People are also selective in choosing and finding information that could support their attitudes or beliefs Festinger's (1) selective exposure hypothesis explains that the effort to reduce dissonance is made by avoiding unsupportive information and selectively seeking supportive information.

A number of studies after Festinger's (1) have proven that selective exposure is not only due to the belief variable. Many other variables may determine people's selective exposure to information or media (see Table 1). Based on the development of the research on the causes of selective exposure (from 1957 to 2010), it has been realized that the factors causing selective exposure are complex and involve several aspects of human life. The psychological aspect is related to the psychological effects of the selective exposure, such as belief, confidence, commitment, and mood. The message aspect is linked to characteristics that influence the selective exposure process, such as the information's utility, assurance, and relevance. The social aspect is associated with the characteristics of the individual as a social being who is part of the social environment, such as the social norms/group and the support group.

\subsection{Utility of information theory}

Cannon (13) first stressed the importance of utility as the basis of selective exposure (8). In his view, a person's behavior concerning selective exposure is not affected by whether the information gives rise to consonance or dissonance but is triggered by the utility of the information for the person.

In 1973, Atkin developed Cannon's notion (8) and refuted Festinger's (1) standpoint. According to Atkin, selective exposure is performed by individuals according to the utility of the information. In the process, individuals will therefore not only select favorable exposure in accordance with their attitudes but may also choose exposure that is harmful or contrary to their beliefs. Atkin focused on "threats and opportunities" as two inter related matters. Hence, the information chosen might not always be appropriate for a person's attitudes and beliefs. Dissonant information might be selected as well, provided that such information has usefulness for the individual, such as for guidance, strengthening his or her attitudes, and instruction on how to do a task.

Some researchers, such as Levy and Windahl (14), developed Atkin's concept. According to them, selection is not determined by whether the information is appropriate or not in accordance with a person's dissonance but by the utility of the information. Such utility will be increased by three determining dimensions: the perceived magnitude of the challenges, the perceived likelihood of their materialization, and the immediacy. The larger the scale of the information is, the more likely, the closer, and the more useful the information will be for an individual.

The studies by Festinger (15), Freedman (16), Freedman and Sears (17), and Frey (7) have also proven that in conducting selective exposure, people not only choose the appropriate information in line with their beliefs but also pay attention to and select the information that has utility, even if it is dissonant.

\subsection{Social identity theory}

The social identity theory (18) explains how a group can affect its members' behavior and often shares certain rules or standards. When someone joins a group, either consciously or unconsciously, there is mutual agreement on what should and should not be done in accordance with the prevailing norms of the group. Such a condition arises from subjective norms, which comprise the individual's beliefs about other persons or what the influential social environment wants him or her to do. It means that individuals who firmly hold a subjective norm will believe that another person will tend to act in line with their subjective norm. If it is violated, either moral (the violator will be exiled, ridiculed, or expelled from the group) or legal sanctions will be imposed.

\subsection{Theoretical model}

The proposed research model links the belief, utility of information, and group support variables to selective exposure. This model has two advantages. First, it lists these three aspects as the causes of selective exposure. So far, the studies on selective exposure have tended to focus only on one factor. The group support variable has rarely been researched. Second, this model simultaneously examines the relationships among these three variables in a single model. Thus, it does not only examine several variables but also tests the integration of all the variables' effects in a whole model that is expected to explain the causes of selective exposure. In this integrated research model the three aspects are assigned as independent variables that are predicted to cause selective exposure behavior. These variables are interrelated and formed in a path model. Based on the research model a hypothesis is formulated as follows: There is a linkage among the effects of belief, the utility of information, and group support on selective exposure.

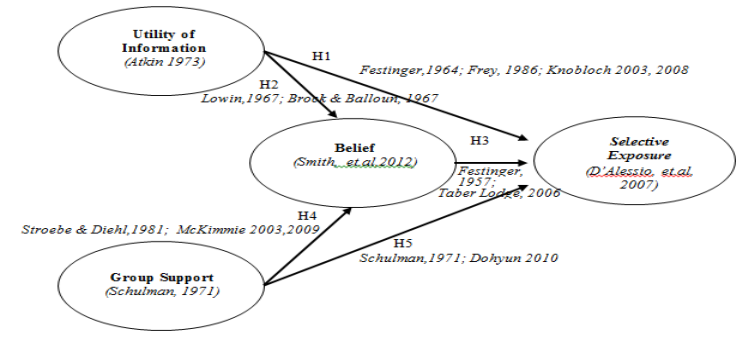

Fig. 1: Model of Belief, Utility of Information, and Group Support Influence on Selective Exposure

The hypotheses on the relationships among the research variables are as follows:

H1. The utility of information influences selective exposure.

$\mathrm{H} 2$. The utility of information influences belief.

H3. Belief influences selective exposure.

H4. Group support influences belief.

H5. Group support influences selective exposure. 


\section{Methodology}

This research uses the positivist or classic paradigm by employing the survey method. The study's subjects represent the population comprising 152,496 public and private high school students in Jakarta in 2015. Using cluster random sampling, the study involves a total sample of 400 survey respondents.

The validity and reliability assessment uses the LISREL 8.80 application and confirmatory factor analysis (CFA). The hypotheses are tested by means of structural equation modeling (SEM). The data collection method employed is a questionnaire. Based on the theory of this research, as well as the hypotheses and the variables' operational definition, the path diagram of this study is described in Figure 2.

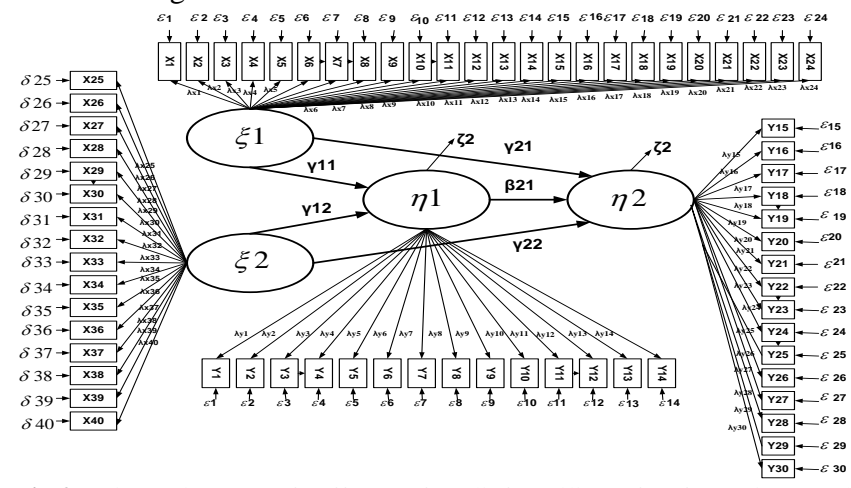

Fig.2: Line Diagram of Effects of Belief, Utility of Information, and Group Support on

Selective Exposure

\section{Results and Findings}

\subsection{Data normality testing}

For the three independent variables, all indicators $(\mathrm{X} 1-\mathrm{X} 24$ for utility of information, X25-X40 for group support, and Y1-Y14 for belief) have a critical ratio (CR) of skewness and kurtosis that is smaller than the \pm 2.58 threshold at the $1 \%$ significance level. It can thus be concluded that for these three variables, the data is distributed normally, that is, normality qualified. The selective exposure variables also qualify as normally distributed data. All the indicators used (Y15-Y30) have a skewness and kurtosis CR smaller than the \pm 2.58 threshold at the $1 \%$ significance level.

\subsection{Model compatibility test (goodness of fit)}

The theoretical integrated models that have been developed to perform the test with the model fit the data. The fit model test results (see Table 2) show that the theoretical model is a fit model. The 17 fit models show good results. Some important measures, such as RMSEA, AIC, and NFI, result in a good modeling size. These test results can already be used to describe the measurement model and the structural relationship model among latent variables.

Table 2: Model Compatibility Scale

\begin{tabular}{|c|c|c|c|}
\hline GOF Sale & $\begin{array}{l}\text { Target- } \\
\text { Compatibility } \\
\text { Level }\end{array}$ & $\begin{array}{l}\text { Estimated } \\
\text { Result }\end{array}$ & $\begin{array}{l}\text { Compatibility } \\
\text { Level }\end{array}$ \\
\hline Chi-Square & $\begin{array}{l}\text { The smaller the } \\
\text { better }\end{array}$ & 47.13 & Relative \\
\hline $\begin{array}{l}\text { Chi-Square I } \\
\text { df }\end{array}$ & $\leq 2.0$ & $47.13 / 50$ & Good \\
\hline $\begin{array}{l}\text { Probability (p } \\
\text { value) }\end{array}$ & $\mathrm{P}$-value $\geq 0.05$ & 0.9998 & Good \\
\hline NCP Interval & $\begin{array}{l}\text { The smaller the } \\
\text { better }\end{array}$ & 47.68 & Relative \\
\hline RMSEA & 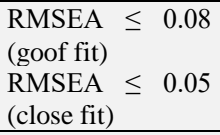 & 0.013 & Good \\
\hline ECVI & Model value close & 10.52 & Good \\
\hline
\end{tabular}

\begin{tabular}{|c|c|c|c|}
\hline & to saturated ECVI & & \\
\hline AIC & $\begin{array}{l}\text { Model value close } \\
\text { to saturated AIC }\end{array}$ & 48.00 & Good \\
\hline CAIC & $\begin{array}{l}\text { Model value close } \\
\text { to saturated CAIC }\end{array}$ & 48.35 & Good \\
\hline NFI & $\begin{array}{l}\mathrm{NFI} \geq 0.90 \text { (good } \\
\text { fit) } \\
0.80 \leq \mathrm{NFI} \leq 0.90 \\
\text { (marginal fit) }\end{array}$ & 0.98 & Good \\
\hline NNFI & $\begin{array}{l}\text { NNFI } \geq 0.90 \\
\text { (good fit) } \\
0.80 \leq \text { NNFI } \leq \\
0.90 \quad \text { (marginal } \\
\text { fit) }\end{array}$ & 0.98 & Good \\
\hline CFI & $\begin{array}{l}\mathrm{CFI} \geq 0.90 \text { (good } \\
\text { fit) } \\
0.80 \leq \mathrm{CFI} \leq 0.90 \\
\text { (marginal fit) }\end{array}$ & 0.98 & Good \\
\hline IFI & $\begin{array}{l}\text { IFI } \geq 0.90 \text { (good } \\
\text { fit) } \\
0.80 \leq \text { IFI } \leq 0.90 \\
\text { (marginal fit) }\end{array}$ & 0.98 & Good \\
\hline RFI & $\begin{array}{l}\text { RFI } \geq 0.90 \text { (good } \\
\text { fit) } \\
0.80 \leq \mathrm{RFI} \leq 0.90 \\
\text { (marginal fit) }\end{array}$ & 0.98 & Good \\
\hline $\mathrm{CN}$ & $\mathrm{CN} \geq 200$ & 7.02 & Good \\
\hline RMR & $\begin{array}{l}\mathrm{RMR} \leq 0.05 \\
\text { (good fit) }\end{array}$ & 0.019 & Good \\
\hline GFI & $\begin{array}{l}\text { GFI } \geq 0.90 \text { (good } \\
\text { fit) } \\
0.80 \leq \mathrm{GFI} \leq 0.90 \\
\text { (marginal fit) }\end{array}$ & 0.99 & Good \\
\hline AGFI & $\begin{array}{l}\text { AGFI } \geq 0.90 \\
\text { (good fit) } \\
0.80 \leq \text { AGFI } \leq \\
0.90 \quad \text { (marginal } \\
\text { fit) }\end{array}$ & 0.99 & Good \\
\hline
\end{tabular}

\subsection{Structural model test}

The structural model test in this research is based on the assumption that selective exposure is a variable that is influenced by belief, the utility of information, and group support. Belief is influenced by the utility of information and group support. The structural model is analyzed by evaluating the coefficients or parameters that indicate a causal relationship or the effect of one construct on other constructs.

The evaluation of the structural model can also be regarded as the hypotheses evaluation or testing. A causal relationship among the constructs is deemed statistically significant at the 0.05 significance level if the value of the $t$ test $\geq 1.96$ (critical value or $t$ table). Table 3 provides the standard estimated value or the structural equation coefficient and the $t$ value of each parameter that describes the causality significance conclusions that have been hypothesized.

\begin{tabular}{|c|c|c|c|c|c|}
\hline $\begin{array}{c}\text { Laten } \\
\text { Independen } \\
\text { t Variable }\end{array}$ & & $\begin{array}{c}\text { Dependen } \\
\text { t Latent } \\
\text { Variable } \\
\end{array}$ & $\begin{array}{c}\text { Paramete } \\
\text { r }\end{array}$ & $\begin{array}{c}\text { Standard } \\
\text { Estimatio } \\
n\end{array}$ & $\begin{array}{c}\text { t- } \\
\text { valu } \\
\text { e }\end{array}$ \\
\hline $\begin{array}{l}\text { Utility of } \\
\text { Information } \\
\text { (X1) }\end{array}$ & $\longrightarrow$ & $\begin{array}{l}\text { Selective } \\
\text { Exposure } \\
\text { (Y2) }\end{array}$ & $\gamma_{21}$ & 0.30 & 3.33 \\
\hline $\begin{array}{l}\text { Utility of } \\
\text { Information } \\
\text { (X1) }\end{array}$ & & $\begin{array}{l}\text { Belief } \\
\text { (Y1) }\end{array}$ & $\gamma_{11}$ & 0.07 & 2.71 \\
\hline Belief (Y1) & $\rightarrow$ & $\begin{array}{l}\text { Selective } \\
\text { Exposure } \\
\text { (Y2) }\end{array}$ & $\beta_{21}$ & 0.01 & 3.75 \\
\hline $\begin{array}{l}\text { Utility of } \\
\text { Information } \\
(\mathrm{X} 2)\end{array}$ & $\longrightarrow$ & $\begin{array}{l}\text { Belief } \\
\text { (Y1) }\end{array}$ & $\gamma_{12}$ & 0.30 & 3.33 \\
\hline $\begin{array}{c}\text { Group } \\
\text { Support } \\
\text { (X2) }\end{array}$ & $\longrightarrow$ & $\begin{array}{c}\text { Selective } \\
\text { Exposure } \\
\text { (Y2) }\end{array}$ & $\gamma_{22}$ & 0.23 & 2.66 \\
\hline
\end{tabular}


Table 3 shows five statistically significant coefficients. Thus, the five hypotheses tested in this study are statistically significant. The research results are described as follows:

\section{H1. The utility of information influences selective exposure.}

The structural model test result shows the significant relationship between the utility of information and selective exposure, which proves the first hypothesis. The more useful a piece of information is, the more it will be selected and searched and vice versa. The result of the path coefficient is 0.30 , and the $t$ value is 3.33 .

Based on the result, it can be concluded that selective exposure is done by individuals to meet their need for information. People will not only notice information that is in accordance with their beliefs but also dissonant information. In other words, the chosen (or the avoided or denied) information is not always appropriate for (or opposed to) people's attitudes and beliefs. The dissonant information will also be selected, as long as it has utility for the individual. It means that only the useful information will be selected, even if it is dissonant. In contrast, although a piece of information is consonant, it will be avoided or denied if it has fewer benefits.

In the case of pornography, as far as the information about it has benefits, it will then be selected. Such benefits can be intended as instructions (how to judge matters), reinforcement (confirmation of an attitude), and performance (how to do a task). In other words, the selective exposure to pornography would be based on a specific goal (purposeful). The more the information about pornography can meet the goal of obtaining the needed information, the more it will be selected and vice versa. In this case, the individual is deemed able to assess both useful and useless information; therefore, the selective exposure process is perceived as an attempt to meet certain objectives related to the utility of the information.

H2. The utility of information influences belief.

The structural model test result shows the significant relationship between the utility of information and belief, which confirms the second hypothesis. The more useful a piece of information is, the stronger the belief in it will be and vice versa. The result of the path coefficient is 0.07 , and the $t$ value is 2.17 .

Based on the result, it can be concluded that a person will not reject or avoid dissonant information, as far as it is useful for presenting a rebuttal or an argument to convince others of one's decisions, opinions, or beliefs. Dissonant information will also be taken into account if the information increases a person's knowledge and improves one's understanding related to something arbitrary. Meanwhile, consonant information is used as a reinforcement of a certain belief. If the consonant information is not considered qualified, then it will not be selected but avoided because it will weaken the belief.

In the case of pornography, information about it will be beneficial to further strengthen the belief that pornography contains data that is contrary to social norms (such as decency, courtesy, faith, and others). On the other hand, information against pornography will undermine the belief if it cannot present the facts showing pornography's potential to damage the morale of a nation, especially teenagers.

\section{H3. Belief influences selective exposure.}

The structural test result shows the significant relationship between belief and selective exposure, which supports the third hypothesis. The stronger the belief is, the more selective the information chosen based on the belief will be and vice versa. This result is seen from the path coefficient of 0.01 and the $t$ value of 3.75 .

The finding supports Festinger's (1) notion of belief as the selective exposure variable. In the theory of cognitive dissonance, to overcome psychological discomfort and achieve cognitive balance, people will look for or choose the information in which they have confidence and will avoid contradictory information $(6,19)$. Some studies supporting Festinger's (1) research include those of Ehrlich et al. (20), Mills, Aronson, and Robinson (21), Adams (22), Freedman and Sears (16), and Taber (23), among others.

In the case of pornography, when people believe that information about it is contrary to their own beliefs, the information will not be selected. Conversely, when their beliefs do not conflict with the information about pornography, then the information will be selected.

\section{H4. Group support influences belief.}

The structural model test result shows the significant relationship between group support and belief, which proves the fourth hypothesis. The greater the group support is, the further will it strengthen the belief and vice versa. The result of the path coefficient is 0.30 , and the $t$ value is 3.33 .

This finding reinforces the results of a number of studies, such as those of Festinger (1), Stroebe and Diehl $(24,25)$, and McKimmie et al. (26). Festinger's research on the members of a sect in Chicago, Illinois (USA) who believe in the doomsday prophecy proves that a group's support reinforces its members' belief. In his book entitled $A$ Theory of Cognitive Dissonance, Festinger (1) confirms that social support is the source of a person's cognitive dissonance; at the same time, it is the primary means to eliminate or decrease the dissonance. Hence, an individual will change his or her belief when it is opposed to that of the group to achieve harmony/cognitive balance.

Stroebe and Diehl's (24) research also shows that group support affects belief. If someone's behavior is supported by one's group, one will be confident that one's behavior is appropriate.

In subsequent studies, Stroebe and Diehl (25) and McKimmie et al. (26) assert that group support is only meaningful if the social group is the primary identity, in which the members' attitudes and behaviors become relevant references of the attitudes and the behaviors of the individuals receiving support. It occurs once a person acquires his or her sense of social identity from the group that he or she admires and connects the group with his or her personal self. When the person's sense of social identity functions, he or she will attempt to behave in line with the norms of the social group to which he or she belongs (18).

Based on the research result, it can be concluded that group support exerts an influence that can strengthen or weaken a person's belief. When one's belief is supported by the group, it will be further strengthened. The group support can mean that the belief is appropriate and does not contradict the group's norms. Conversely, the less the group support is, the weaker one's belief will be. Consequently, a person will change his or her belief to achieve cognitive balance with the group to which he or she belongs. In the case of pornography, the more the group does not support the information on pornography (such as issuing Pornography Act No. 44 of 2008 by the Indonesian government), the more reinforced will be the belief that pornography must be strongly resisted. Conversely, when the group support of the information on pornography becomes stronger, the belief that pornography should be avoided and rejected will weaken.

\section{H5. Group support influences selective exposure.}

The structural model test result shows the significant relationship between group support and selective exposure, which supports the fifth hypothesis. The greater or stronger the group support of the information is, the more likely will the information be selected. The less or weaker the group support of the information is, the more likely will the information be avoided. The result of the path coefficient is 0.23 , and the $t$ value is 2.66 .

This result reinforces the findings of Festinger (1), Knobloch (9), and Chen (27), which prove that group support likely affects selective exposure. In the context of selective exposure, a person prefers certain information when the group's support of the information strengthens. For example, when the group's members watch TV a lot, it will likely make a co-member watch a TV program that is also watched by the group. The group's practices or habits become important guidelines for how a member acts and behaves.

Based on the research result, the information that obtains group support will be taken into consideration, while the information that lacks group support will be avoided or denied. The reason is that people seek to achieve cognitive balance and harmony with their social environment as the reflection of social creatures.

In the case of pornography, people will avoid it when the group support of the information weakens. Such avoidance is an attempt 
to achieve balance with the social environment because a detour from the group will often result in social/moral sanctions (in the form of exclusion or derision) and even criminal sanctions. On the contrary, people will choose information about pornography when the group support of the information strengthens. For example, many adolescents access information about pornography just because they do not want to be considered old-fashioned or unmanly and be ostracized by their peer group (28).

\subsection{Analysis of Findings}

Some important findings emerge from the model testing. First, the structural test results show the significant influence of the three variables (belief, the utility of information, and group support) on selective exposure $(t$ value $\geq 1.96)$. These three variables affect selective exposure in an integrated manner, which also means that all five research hypotheses are proven in accordance with the theoretical model $(\mathrm{H} 0=$ accepted $)$.

The result of the structural model test also provides evidence that selective exposure is not only caused by one aspect but also by the integration of various aspects. This research proves in a single theoretical model that the integration of belief, the utility of information, and group support influences selective exposure. Second, based on the theoretical models, the utility of information variable has a stronger influence on selective exposure (structura coefficient of 0.30) than group support and belief. The belief variable has the weakest influence on selective exposure (structural coefficient of 0.01). On the other hand, group support has a stronger influence on belief (structural coefficient of 0.30 ) compared to the utility of information (structural coefficient of 0.07). Considering the structural model test results, the researcher assumes that the stronger influence of the utility of information variable on selective exposure reflects the impact of human life on the abundance of information as a result of technology advancement. The development of electronic communication media has changed the approach to communication. The conventional media, which basically offers the "one-to-many" communication model (e.g. newspapers, television, radio, etc.) has shifted to the "many-toone" (e.g., e-mail, websites, etc.) and the "many-to-many" (e.g., mailing list, groups in the smartphone, e-discussion, etc.) models in the new media. Such a shift in the mass communication approach related to the information technology development has resulted in an explosion of information, which is constantly flowing into private life. In the context of pornography, the shift in the communication approach from the one-to-many model to the many-to-one and the many-to-many models is speeding up the dissemination of information about pornography. In anticipating the abundance of pornographic information, individuals will choose the information that is considered beneficial according to their interests and needs. Their selective exposure based on interests and needs also proves that people are actively engaged in processing information.

The research findings also reinforce Atkin's (8) notion as outlined in the utility of information theory, which states that a person's motivation in selective exposure is not caused by whether the information gives rise to consonance or dissonance but is triggered by the utility of the information for the person. The information's usability/benefit can only be gained when someone has an orientation purpose based on the self-adjustment goal to be achieved through the acquisition of information, either negative or positive (threat or opportunity), because each information is believed to have advantages. The information can be used to meet a person's need for instructions (how to judge matters), reinforcement (confirmation of an attitude), and performance (how to do a task). As selective exposure is based on a benefit/utility, a person will not only select the information that is beneficial or in line with his or her belief but will also shortlist the information that is harmful or contrary to his or her belief.

In the case of pornography, adolescents actually require knowledge of sex, considering that sex is also associated with adolescent psychological development. By obtaining information about sex, adolescents can learn to make decisions in a mature way, and being guided and briefed about the sex organ functions reflect the stages that must be undergone in human life. In other words, knowledge about sex benefits adolescents in gaining a better understanding of what sex really is and helps them go through each psychological development related to sex itself. The utility of the information about sex that is perceived by adolescents makes teenagers often choose pornographic information, although it may be contrary to their beliefs.

Another variable that shows significant influence on selective exposure is group support. The research results show that the respondents' selective exposure does not only consider personal interests but also the values and norms of social groups, such as decency, courtesy, politeness, and others. As part of the community, the respondents require the support of social groups, from either the closest one (parents or peers) or the more distant one (neighborhood), on the selective exposure to pornography. The results are also in accordance with the notion of the social identity theory that the more a person is loyal to the group, the more effective will be his or her social communication behaviors in accordance with the prevailing group norms.

In the case of pornography, the selected respondents express approval of pornography if it is supported by the primary group. Otherwise, they express disapproval of the information about pornography if it is not supported by the local community (secondary group). From these results, it appears that group support affects the selective exposure to pornography. Selective exposure based on group support reflects a person's effort to achieve balance with the social environment because a detour from the group will often result in social/moral sanctions (in the form of exclusion or derision) and even criminal sanctions.

The researcher argues that the results provide evidence that people are social beings. In the cognitive dissonance theory, belief is positioned as a set of values that is communicated to someone (through the family at first) and is stored cognitively. The belief in human beings serves as a psychological disposition. The main premise of selective exposure, which positions belief as a variable influencing selective exposure, is a form of interpersonal communication. Hence, it is a form of self-communication based on values that are believed to make a selective exposure.

Furthermore, as social beings, people interact with one another. The communication established in the environmental/social groups, at both interpersonal and group levels, can affect a person's beliefs. The strength of the environment/group's influence on the person's beliefs is determined by how close the person is to the group and how great is the person's need to maintain communication with the group/social environment. The closer the person is to the group and the greater the need is, the more powerful is the environment/group's influence on the person's beliefs and vice versa.

In short, the interactions that occur within the group, both interpersonal and collective, can affect belief. A belief, which is the value embedded in oneself, can shift according to the group's subjective norms due to the communication that exists between the individual and the group.

Addressing the weak relationship between the utility of information and belief, the researcher assumes that in the context of the research on selective exposure to pornography, the utility of information is viewed with the aim to increase the knowledge about pornography instead of strengthening or weakening the belief in it. Thus, the utility of information is intended to fulfill the need for information, instead of supporting or controlling belief.

The research also shows the belief variable's significant relationship to selective exposure ( $t$ value of 3.75 ) but weaker influence (path coefficient of 0.01 ) compared to the utility of information (path coefficient of 0.30 ) and group support (path coefficient of 0.23 ). Several factors can be elaborated to explain these findings. First, the relationship between belief and selective exposure amplifies the main premise that the belief variable influences selective exposure. 
Second, the weak influence of belief on selective exposure must be understood in the context of pornography. As a psychological disposition (a value that is believed by and ingrained in an individual), belief does not play an absolute role in influencing selective exposure to pornography. The environment/social group perform more functions in this case. A belief may change due to the communication that exists between the individual and the environment/social group. This is understandable, given that collectivist cultural patterns tend to be embraced by the majority of Indonesians. In collectivist cultures, decisions are often determined by the norms of society or interdependent views that always emphasize harmonious group relations. In contrast, in individualistic cultures, decisions are mostly made rationally and independently by each person based on self-consideration $(29,30)$.

Third, in the context of pornography, selective exposure tends to be based on the need for information instead of belief (31). Instinctively, people are interested in taboo subjects such as pornography. For adolescents, their need for pornographic information is not only due to their interest in what is forbidden but also because of the motivation and the demands of biological and psychological developments. This situation makes adolescents often try to seek information about sex to increase their self-knowledge. As a result of their need for sex information (which is deemed beneficial) and the limited formal resources, such information is much sought after and chosen. Such condition has made adolescents the largest age group that enters the keyword "sex" on Internet search engines.

\section{Conclusion}

This research is based on the starting point that the selective exposure factor cannot only be explained by one variable but must be discussed holistically (combined with various aspects). This assumption is based on previous studies that have proven that selective exposure can be caused by more than one variable from various perspectives. In this regard, the researcher recognizes the standpoint from which to examine the influence of the integration of three variables (belief, the utility of information, and group support) on selective exposure, using a single research model.

By taking the case of pornography, the researcher has sought to draw conclusions on whether the integration of these three variables has been proven to affect selective exposure. This case study is based on the argument that pornography is one of the social problems with an iceberg phenomenon in Indonesia that needs serious attention. The reason for selecting adolescents as the respondents is that they comprise the largest age group targeted by pornography.

Generally, the research results prove that selective exposure can be caused by the integration of the three variables.

On the other hand, pornography, which is heavily publicized through various forms of communication media, will ultimately lead to the media effect. The media effect will depend on the existing reality (e.g., peer group). If the reality is in line with a person's belief, which is to prohibit or refuse pornography, then the belief will not change. On the contrary, when the reality does not prohibit pornography but the person's belief forbids it, the belief may change. The change in the belief depends on how close the relationship is between the individual and the reality. The closer the relationship is, the more quickly will the belief change and vice versa. The changes made embody the effort to achieve cognitive balance.

Therefore, the researcher concludes that the communication in the context of selective exposure to pornography is divided into three levels. First, at the intrapersonal level, people will hold their belief in selective exposure. Second, at the interpersonal or group level, people will adjust their belief to the existing reality (the environment/social group). Third, at the mass communication level, the selective exposure is done based on the utility of the information to meet the need for it.

Finally, although this study is not intended to examine the impact of media, indirectly, the research model shows that human beings are not passive in processing information related to the impact of mass communication. Many factors influence the decision about selective exposure, including the psychological aspect, the message, or the social environment. Developments in information and communication technology have enabled people to choose and pick up a lot of information or news. The cornucopia of communication makes people actively engaged in selective exposure in accordance with their own cognitive processes.

\section{References}

[1] Festinger L. A theory of cognitive dissonance. Vol. 207, Scientific American. 1957. p. 291.

[2] Editorial Kompasiana. Tingkat Akses Pornografi Internet. Kompasiana. 2015. p.

[3] Bennett WL, Iyengar S. A new era of minimal effects? The changing foundations of political communication. J Commun. 2008;58(4):707-31.

[4] Stroud NJ. Media use and political predispositions: Revisiting the concept of selective exposure. Polit Behav. 2008;30(3):341-66.

[5] Miller K. Organizational communication. Vol. 33, Communication Education. 2005. 197-201 p.

[6] Sears DO, Freedman JL. Selective exposure to information: A critical review. Public Opin Q. 1967;31(2):194-213.

[7] Frey D. Recent Research on Selective Exposure to Information. Adv Exp Soc Psychol. 1986;19(C):41-80.

[8] Knobloch S, Carpentier FD, Zillmann D. EFFECTS OF SALIENCE DIMENSIONS OF INFORMATIONAL UTILITY ON SELECTIVE EXPOSURE TO ONLINE NEWS. Journal Mass Commun Q. 2003;80(1):91-108.

[9] Knobloch-Westerwick S, Hastall MR. Please your self: Social identity effects on selective exposure to news about in- and outgroups. J Commun. 2010;60(3):515-35.

[10]1Redlawsk DP. Hot Cognition or Cool Consideration? Testing the Effects of Motivated Reasoning on Political Decision Making. J Polit. 2002;64(4):1021-44.

[11]Hutagalung I. SELECTIVE EXPOSURE AND CONSUMER BEHAVIOR - INTERPRETATIVE PHENOMENOLOGICAL ANALYSIS IN CONSUMER BEHAVIOR OF Z GENERATION ADOLESCENT ON THE AD INFORMATION OF SMARTPHONE SELECTION. Int J Organ Innov. 2016;9(2):85-91

[12]Littlejohn SW, Foss KA. Theories of Human Communication. Higher Education. 2008. 396 p.

[13]13. Zillmann D, Bryant J. Selective exposure to communication. In: Cognitive dissonance in selective exposure. 1985. p. 11-33.

[14] Knobloch-Westerwick S, Carpentier FD, Blumhoff A, Nickel N. Selective exposure effects for positive and negative news: Testing the robustness of the informational utility model. Journal Mass Commun Q. 2005;82(1):181-95.

[15]Festinger L. Conflict, decision, and dissonance. Confl Decis dissonance. 1964;1-163.

[16]Freedman JL. Confidence, utility, and selective exposure: a partial replication. J Pers Soc Psychol. 1965;2(5):778-80.

[17] Freedman DOS and JL. Selective Exposure to Information. Public Opin Q. 1967;31(2):194-213.

[18] Severin WJ, Tankard Jr. JW. Communication Theories. Crit Perspect. 2001;61.

[19] Cooper J. Cognitive dissonance theory. Handb Theor Soc Psychol (Vol 1). 2012;(November):377-97.

[20]Ehrlich D, Guttman I, Schoenbach P, Mills J. Postdecision exposure to relevant information. J Abnorm Soc Psychol. 1957;54:98-102.

[21]Mills J, Aronson E, Robinson H. Selectivity in exposure to information. J Abnorm Soc Psychol. 1959;59:250-3.

[22] Adams JS. Reduction of cognitive dissonance by seeking consonant information. J Abnorm Soc Psychol. 1961;62(1):74-8.

[23] Taber CS, Lodge M. Motivated skepticism in the evaluation of political beliefs. Am J Pol Sci. 2006;50(3):755-69.

[24] Stroebe W, Diehl M. Conformity and counterattitudinal behavior: The effect of social support on attitude change. J Pers Soc Psychol. 1981;41(5):876-89.

[25] Stroebe W, Diehl M. When social support fails: Supporter characteristics in compliance-induced attitude change. Pers Soc Psychol Bull. 1988;14(1):136-44.

[26]McKimmie BM, Terry DJ, Hogg MA, Manstead ASR, Spears R, Doosje B. I'm a hypocrite, but so is everyone else: Group support and the reduction of cognitive dissonance. Gr Dyn Theory, Res Pract. 2003;7(3):214-24.

[27]Chen JM, Kim HS, Mojaverian T, Morling B. Culture and Social Support Provision: Who Gives What and Why. Personal Soc 
Psychol Bull. 2012;38(1):3-13.

[28]Lestary H, Sugiharti. Perilaku Berisiko Remaja Di Indonesia Menurut Survey Kesehatan Reproduksi Remaja Indonesia ( Skrri ) Tahun 2007. J Kesehat Reproduksi. 2011;1(3):136-44.

[29] Markus HR, Kitayama S. Culture and the self: Implications for cognition, emotion, and motivation. Psychol Rev. 1991;98(2):22453.

[30] Hoshino-Browne E, Zanna AS, Spencer SJ, Zanna MP, Kitayama S,
Lackenbauer S. On the cultural guises of cognitive dissonance: the case of easterners and westerners. J Pers Soc Psychol. 2005;89(3):294-310.

[31] Supriati E, Fikawati S. EFEK PAPARAN PORNOGRAFI PADA REMAJA SMP NEGERI KOTA PONTIANAK TAHUN 2008 Effect of Pornography Exposure on Junior High School Teenagers of Pontianak in 2008. Makara Sos Hum. 2009;13(1):48-56. 